\title{
Front Matter: Volume 11064
}

, "Front Matter: Volume 11064," Proc. SPIE 11064, Tenth International Conference on Thin Film Physics and Applications (TFPA 2019), 1106401 (8 November 2019); doi: 10.1117/12.2542048

SPIE Event: Pacific Rim Laser Damage 2019 and Thin Film Physics and SPIE. Applications 2019, 2019, Qingdao, China 


\title{
PROCEEDINGS OF SPIE
}

\section{Tenth International Conference on Thin Film Physics and Applications (TFPA 2019)}

\author{
Junhao Chu \\ Jianda Shao \\ Editors
}

\section{9-22 May 2019 \\ Qingdao, China}

Sponsored by

SPIE

SIOM-Shanghai Institute of Optics and Fine Mechanics (China)

Chinese Physical Society (China)

Shanghai Physical Society (China)

Organized by

Chinese Laser Press

Qingdao University (China)

Shandong Society for Optical Engineering (China)

Cooperating Organizations

Chinese Academy of Sciences

The National Natural Science Foundation of China

Qingdao Physical Society (China)

Published by

SPIE

\section{Volume 11064}


The papers in this volume were part of the technical conference cited on the cover and title page. Papers were selected and subject to review by the editors and conference program committee. Some conference presentations may not be available for publication. Additional papers and presentation recordings may be available online in the SPIE Digital Library at SPIEDigitalLibrary.org.

The papers reflect the work and thoughts of the authors and are published herein as submitted. The publisher is not responsible for the validity of the information or for any outcomes resulting from reliance thereon.

Please use the following format to cite material from these proceedings:

Author(s), "Title of Paper," in Tenth International Conference on Thin Film Physics and Applications (TFPA 2019), edited by Junhao Chu, Jianda Shao, Proceedings of SPIE Vol. 11064 (SPIE, Bellingham, WA, 2019) Seven-digit Article CID Number.

ISSN: 0277-786X

ISSN: 1996-756X (electronic)

ISBN: 9781510628182

ISBN: 9781510628199 (electronic)

Published by

SPIE

P.O. Box 10, Bellingham, Washington 98227-0010 USA

Telephone +1 3606763290 (Pacific Time) · Fax +1 3606471445

SPIE.org

Copyright (c) 2019, Society of Photo-Optical Instrumentation Engineers.

Copying of material in this book for internal or personal use, or for the internal or personal use of specific clients, beyond the fair use provisions granted by the U.S. Copyright Law is authorized by SPIE subject to payment of copying fees. The Transactional Reporting Service base fee for this volume is $\$ 21.00$ per article (or portion thereof), which should be paid directly to the Copyright Clearance Center (CCC), 222 Rosewood Drive, Danvers, MA 01923. Payment may also be made electronically through CCC Online at copyright.com. Other copying for republication, resale, advertising or promotion, or any form of systematic or multiple reproduction of any material in this book is prohibited except with permission in writing from the publisher. The CCC fee code is $0277-$ $786 \mathrm{X} / 19 / \$ 18.00$.

Printed in the United States of America by Curran Associates, Inc., under license from SPIE.

Publication of record for individual papers is online in the SPIE Digital Library.

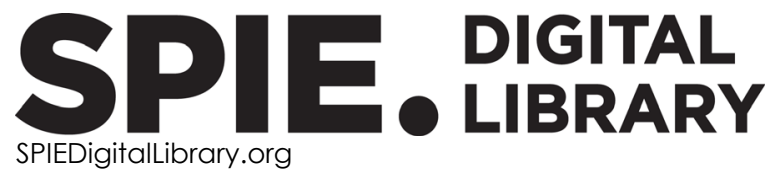

Paper Numbering: Proceedings of SPIE follow an e-First publication model. A unique citation identifier (CID) number is assigned to each article at the time of publication. Utilization of CIDs allows articles to be fully citable as soon as they are published online, and connects the same identifier to all online and print versions of the publication. SPIE uses a seven-digit CID article numbering system structured as follows:

- The first five digits correspond to the SPIE volume number.

- The last two digits indicate publication order within the volume using a Base 36 numbering system employing both numerals and letters. These two-number sets start with $00,01,02,03,04$, 05, 06, 07, 08, 09, OA, OB ... 0Z, followed by 10-1Z, 20-2Z, etc. The CID Number appears on each page of the manuscript. 


\title{
Contents
}

\author{
vii Authors \\ ix Conference Committee
}

\section{SESSION 1 THIN FILM MATERIALS I}

1106402 Influence of transition layer on the surface scattering of unmodified silicon carbide [1 1064-55]

SESSION 2 TECHNOLOGY OF THIN FILMS I

1106403 Thickness dependence of $\mathrm{Cr}$-doped $\mathrm{VO}_{2}$ thin films deposition by reactive pulsed magnetron sputtering [11064-45]

SESSION 4 TECHNOLOGY OF THIN FILMS II

1106404 Preparation of silica thin film by hot pressing process for passive radiative cooling [1 1064-22]

SESSION 5 THIN FILM MATERIALS II

1106405 Optical functions of fishnet metamaterial embedded in dielectrics [1 1064-54]

1106406 Optical and electrical characteristics of radio frequency sputtered ITO and In-free transparent conductors (Invited Paper) [1 1064-6]

1106407 Investigation on tuning of $\mathrm{WS}_{2} / \mathrm{SiC}$ band gap with an external electric field [1 1064-17]

1106408 Enhance anti-water ability of high transmittance film in mid-infrared band [1 1064-14]

1106409 Performance of a spectral beam combining grating with YAG substrate [1 1064-48]

\section{SESSION 6 APPLICATION OF THIN FILMS I}

11064 OA Efficient broadband light absorption enhancement in InP/ZnO core-shell nanocone arrays for photovoltaic application [1 1064-11] 
$11064 \mathrm{OB} \quad$ Energy flow difference structure design based on micro hemisphere structure [11064-23]

$110640 C \quad$ A lift-off of pattern structures on the heat-mode resists [1 1064-19]

11064 OD Positive and negative properties of laser heat-mode resists [1 1064-33]

\section{SESSION $8 \quad$ APPLICATION OF THIN FILMS II}

$11064 \mathrm{OE} \quad$ Wide-incident angle and low polarization aberration edge filter [1 1064-24]

$11064 \mathrm{OF} \quad$ Subwavelength periodic nanostructures fabricated by femtosecond laser in metal, dielectric and metal-dielectric-metal coating [1 1064-53]

POSTER SESSION 11064

$110640 \mathrm{OG}$ Employing $\mathrm{Ni}-\mathrm{Cr}$ co-doping to prepare low phase transition temperature $\mathrm{VO}_{2}$ film [1 1064-57]

$11064 \mathrm{OH} \quad$ Annealing effects on optical and structural properties of $\mathrm{TiO}_{2}$ thin films deposited by ion beam sputtering [11064-18]

$110640 \mathrm{O} \quad$ Broadband chirped volume Bragg grating for one-hundred-femtosecond pulse compression [11064-50]

$110640 \mathrm{~J} \quad$ Broadband polarization beam splitter based on subwavelength grating in Terahertz [1 1064-5]

11064 OK Comparison of mechanical properties evolution of polyimide films in space radiation environment [1 1064-4]

$11064 \mathrm{OL} \quad$ Correlation between the structure and laser damage properties of ion assisted $\mathrm{HfO}_{2}$ thin films [11064-12]

11064 OM Design and fabrication of antireflective surface microstructures on lithium triborate [1 1064-51]

11064 ON Design of linear polarizer in $3-13 \mu \mathrm{m}$ broad infrared region with multilayer nanostructures [11064-30]

1106400 Effect of $\mathbf{M g F} 2$ deposition temperature on Al mirrors in vacuum ultraviolet [1 1064-42]

$11064 \mathrm{OP} \quad$ Effect of temperature on optical properties of $\mathrm{CeO}$ film being irradiated by $\mathrm{Co}^{60}$ prepared by RF magnetron sputtering [1 1064-8]

$110640 Q$ Effects of different oxygen flow on refractive index and absorption characteristics of $\mathrm{Ta}_{2} \mathrm{O}_{5}$ film [11064-37] 
11064 OR Efficient method for determination of laser conditions adopted in laser-induced micro-lithology based on laser polymerization size analysis [1 1064-34]

11064 OS Electrical property of OSR second surface mirror in space radiation environments [11064-3]

11064 OT Experimental observation and numerical analysis for dynamical output in free-running multilongitudinal mode erbium doped fiber ring laser [1 1064-15]

11064 OU Green vegetables derived simultaneously carbon dots as sensitizer and carbon particles as counter electrode for dye-sensitized solar cells [1 1064-26]

11064 OV Improvement on fluorescent properties of photonic crystals filled by quantum dots based on multi-layer films [1 1064-2]

11064 OW Oblique incidence reflectance of resonators based on suspended two-dimensional membranes [11064-40]

11064 OX Optical design of perovskite/silicon laminated solar cells based on grating structure [1 1064-58]

11064 OY Optimization of morphology and electrochemical characteristics of nickel film by sputtering pressure [1 1064-38]

$110640 Z$ Photoelectric properties of transparent conductive metal mesh films based on crack template and its application in Perovskite solar cells [1 1064-46]

1106410 Preparation and physical properties of germanium thin films [1 1064-25]

1106411 Research on the time and mechanism of laser-induced air plasmas ignition [11064-36]

1106413 Study on band gap and dispersion model of $\mathrm{Al}_{2} \mathrm{O}_{3}$ thin films with different oxygen flow rates by ion beam sputtering [11064-32]

$1106414 \quad$ Study on preparation process and shielding effectiveness of graphene films [11064-35]

1106415 Annealing effects on the optical and structural properties of $\mathrm{Y}_{2} \mathrm{O}_{3}$ thin films deposited by thermal evaporation technique [11064-29]

1106416 Development of transparent oxide thin films for flexible devices [1 1064-21]

1106417 Influence of deposition temperature and precursor pulse time on properties of $\mathrm{SiO}_{2}, \mathrm{HfO}_{2}$ monolayers deposited by PEALD [1 1064-39] 
Proc. of SPIE Vol. 11064 1106401-6 Downloaded From: https://www.spiedigitallibrary.org/conference-proceedings-of-spie on 26 Apr 2023
Terms of Use: https://www.spiedigitallibrary.org/terms-of-use 


\section{Authors}

Numbers in the index correspond to the last two digits of the seven-digit citation identifier (CID) article numbering system used in Proceedings of SPIE. The first five digits reflect the volume number. Base 36 numbering is employed for the last two digits and indicates the order of articles within the volume. Numbers start with 00, 01, 02, 03, 04, 05, 06, 07, 08, 09, 0A, OB...0Z, followed by 10-12, 20-2Z, etc.

Bai, Yunli, 02

Cao, Hongchao, 09, 0M

Cao, Zhen, OF

Chen, Dan, $\mathrm{OH}, 13,15$

Chen, Fengnan, $\mathrm{OW}$

Chen, Guodong, OC, OD

Chen, Junming, 09

Chen, Peng, 09, 01

Cheng, Yuyang, $0 \mathrm{~J}$

Dai, Huifang, Ol

Fan, Ping, 03, OG

Fan, Xiaochun, OB

Fu, Bo, OP

Fu, Haiyan, $\mathrm{OZ}$

Fu, Xiuhua, 08

Gao, Enlei, OX

Grilli, Maria Luisa, 06, OF

Guan, Huan, 03, OG

Guo, Meng, 10

He, Dongbing, $\mathrm{Ol}$

$\mathrm{He}$, Hongbo, OF, OM, 10

$\mathrm{He}$, Qicong, OG

$\mathrm{He}$, Shikun, OE

Hu, Guohang, 05, OF

Huang, Lu, OV

Huang, Ping, OU, OY

Huang, Qiaolin, OE

Huang, Ying, $O G$

Huo, Tonglin, $0 O$

$\mathrm{Ji}$, Yiqin, $\mathrm{OQ}$

Jiang, Chenghui, $O Q$

Jiang, Kai, 16

Jiang, Yugang, $\mathrm{OH}, \mathrm{OQ}, 13,15$

Jin, Jingcheng, OG

Jin, Yunxia, 09, Ol, OM

Kong, Fanyu, 09, 0l, 0M

Kong, Weijin, OJ

Kuang, Yawei, OX

Li, Caiyu, OJ

Li, Cheng, OR

Li, Dawei, OR

Li, Shida, OH, OQ, 13, 15

$\mathrm{Li}$, Shuangying, $0 \mathrm{O}$

Li, Xiao, OK

Li, Yuanjie, 16

Liv, Chen, OY

Liu, Dandan, 13

Liv, Dengwu, 04

Liu, Hai, OT

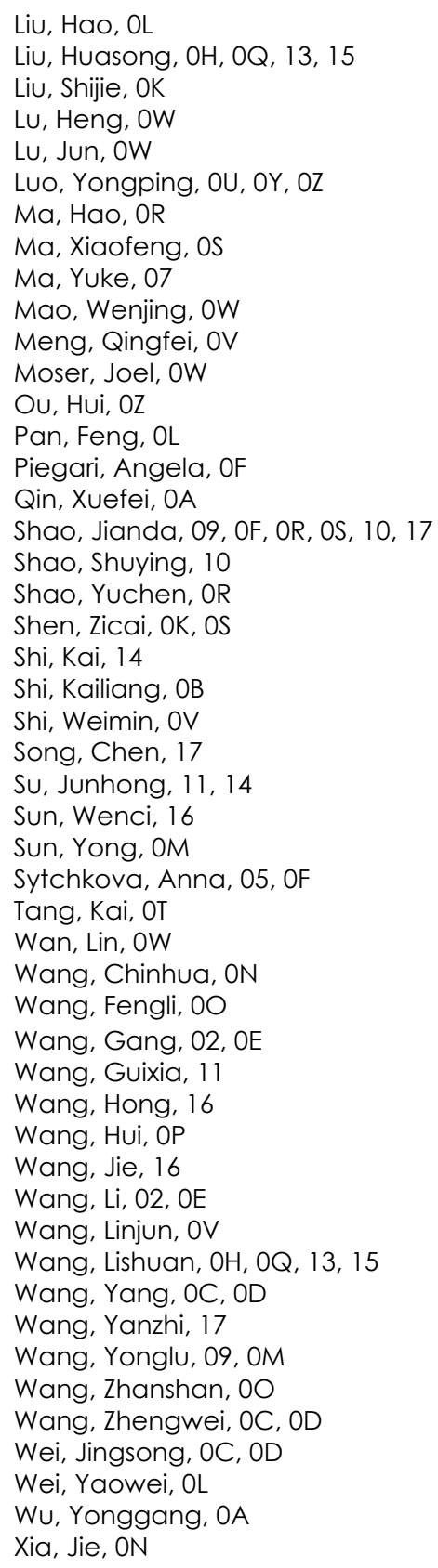

Xia, Jie, ON 
Xia, Zhilin, 04, OB

Xia, Zihuan, OA

Xiang, Zaikui, OP

Xiao, Pengda, OX

Xiao, Yanping, OT

Xiao, Zonghu, OU, OZ, OY

$\mathrm{Xu}$, Jiao, 09

$X u, N \cup o, 17$

$\mathrm{XU}$, Shunjian, OU, OY, OZ

$X u, X i a n ' g a n g, 07$

Xue, Dongbai, 15

Yan, Rongrong, 14

Yan, Ying, OW

Yang, Chen, OW

Yang, Xiao, 15

Yang, Yu, OG

Yi, Kui, 10, 17

Yin, Chaoyi, 17

Yuan, Zhihao, ON

Zeng, Tingting, 17

Zhang, Dongping, 03, 0G

Zhang, Fei, OL

Zhang, Gong, 08

Zhang, Jiyou, 02, OE

Zhang, Kaixin, $\mathrm{OF}$

Zhang, Kui, OC, OD

Zhang, Kun, OJ

Zhang, Meng, OU

Zhang, PuHeng, OT

Zhang, Yelan, $0 \mathrm{~J}$

Zhang, Yibin, 09, 0I, OM

Zhang, Zhenfei, 04

Zhang, Zhuangzhuang, 00

Zhang, Zongyi, OA

Zhao, Jianle, 14

Zhao, Jingyin, 0

Zhao, Yuan'an, OF, OR, 17

Zheng, Hao, OX

Zheng, Xinyu, OX

Zhong, Wei, OU, OY, OZ

Zhou, Hongjun, 00

Zhou, Jian, $\mathrm{OA}$

Zhou, Xin, 14

Zhou, Yuming, 02, OE

Zhu, Meiping, OH, OQ, OS, 13, 15, 17

Zhu, Yitai, OX

Zhu, Yubin, OV 


\title{
Conference Committees
}

\author{
Conference Chairs
}

Junhao Chu, Shanghai Institute of Technical Physics (China) and East China Normal University (China)

Jianda Shao, Shanghai Institute of Optics and Fine Mechanics Sciences (China)

Conference Secretariats

Meiping Zhu, Shanghai Institute of Optics and Fine Mechanics (China)

Jingping Li, Shanghai Institute of Optics and Fine Mechanics (China)

Jiaqi Yan, Chinese Laser Press (China)

Technical Program Committee

Ruxin Li, (Chairman) Shanghai Institute of Optics and Fine Mechanics (China)

Shining Zhu, Nanjing University (China)

Min Gu, RMIT University (Australia)

Andrea C. Ferrari, University of Cambridge (United Kingdom)

Sam Zhang, Nanyang Technological University (Singapore)

Frank Placido, University of the West of Scotland (United Kingdom)

Alexander V. Tikhonravov, M. V. Lomonosov Moscow State University (Russian Federation)

Angela M. Piegari, Italian National Agency for New Technologies, Energy and Sustainable Economic Development (ENEA), Casaccia Research Centre (Italy)

Chang Kwon Hwangbo, Inha University (Korea)

Enam A. Chowdhury, The Ohio State University (United States)

Long Zhang, Shanghai Institute of Optics and Fine Mechanics (China)

Organizing Committee

Long Zhang, Shanghai Institute of Optics and Fine Mechanics (China)

Ya Cheng, Shanghai Institute of Optics and Fine Mechanics (China)

Yaping Dai, China Academy of Engineering Physics (China)

Hongbo He, Shanghai Institute of Optics and Fine Mechanics (China)

Guixue Huang, National High Technology Research and Development (China)

Yuxin Leng, Shanghai Institute of Optics and Fine Mechanics (China)

Liejia Qian, Shanghai Jiao Tong University (China) 
Kui Yi, Shanghai Institute of Optics and Fine Mechanics (China)

Weijing Kong, Qingdao University (China)

\section{Session Chairs}

1 Thin Film Materials I

Sam Zhang, Southwest University (China)

Aimin Chang, Xinjiang Technical Institute of Physics and Chemistry (China)

2 Technology of Thin Films I

Qing Peng, The University of Alabama (United States)

Rong Chen, Huazhong University of Science and Technology (China)

3 Physics of Thin Films I

Vladimir Pervak, Ludwig-Maximilians-Universität München (Germany)

4 Technology of Thin Films II

Min Gu, University of Shanghai for Science and Technology (China)

Maria Luisa Grilli, ENEA Casaccia Research Centre (Italy)

5 Thin Film Materials II

Ivan Kislyakov, Shanghai Institute of Optics and Fine Mechanics (China)

Xiujian Zhao, Wuhan University of Technology (China)

6 Application of Thin Films I

Shigeng Song, University of the West of Scotland (United Kingdom)

Liangyao Chen, Fudan University (China)

7 Physics of Thin Films II

Chang Kwon Hwangbo, Inha University (Korea, Republic of)

8 Application of Thin Films II

Alexander V. Tikhonravov, M.V. Lomonosov Moscow State University (Russian Federation)

Dingquan Liu, Shanghai Institute of Technical Physics (China) 